\title{
U.S. EXECUTIVES' PERCEPTIONS OF "BEMS" AS F.D.I. OPTIONS
}

\author{
Troy A. Festervand \\ Middle Tennessee State University \\ Murfreesboro, TN
}

\begin{abstract}
In this study, perceptual mapping was used to identify the collective and individual positions of ten big emerging markets or "BEMs" as they are more commonly called. The perceived position of the "ideal" market or nation also was captured by the study's findings. FDI executives who were surveyed indicated that some "BEMs" have positioned themselves strategically in terms of their availability of and access to markets and resources. The stability of a market's or nation's political and economic environments, as well as business environment, also contributes to a nation's perceived position. Some "BEMs" appear better positioned to take advantage of their strengths, whereas others face long-term FDI obstacles.
\end{abstract}

\section{Introduction}

Foreign Direct Investment (FDI) is an integral component of the globalization of the world's economy, as well as a key aspect of every nation's economic development efforts. Virtually all nations are eager to attract FDI, as evidenced by the immense financial investments that developing and developed nations have attracted and continue to attract (Jenkins, 1995; UN 1998 and 1999). Indeed, the success of a given nation in attracting foreign capital is a direct result of that nation's market or resources attractiveness, or both, and the presence and availability of investment opportunities (Aitken, et al., 1997).

In recent years, the social, economic, and political environments governing foreign direct investment in many previously closed economies have undergone something of a metamorphosis (Boycko, et al., 1994; Kamm, 1992; Sachs and Warner, 1995). These nations have changed from essentially closed economies or markets advocating protectionism, subsidies, and increased regulations to more market and growth-oriented positions espousing regulatory reform, market expansion, and private sector development. In turn, these changes have encouraged many foreign direct investors to revise their list of nations considered desirable FDI candidates. While still largely comprised of developed nations, many FDI lists now include nations known as "BEMs," big emerging markets. In this instance, a big emerging market's status is not a function of its per capita GNP, but relies on economic and 
demographic measures that cut across all four stages of economic development (Garten, 1997).

"BEMs" consist of nations located around the globe that have experienced rapid economic growth for the past decade (Keegan and Green, 2003). It is because of this rapid growth and the resulting market opportunities that the Columbia Journal of World Business dedicated a special issue to "BEMs" (1996). ${ }^{1}$ Ten countries generally are recognized as big emerging markets. These nations include China, India, Indonesia, South Korea, Brazil, Mexico, Argentina, South Africa, Poland, and Turkey (Garten, 1997).

In the past, the US has invested mightily in emerging nations, both big and otherwise. However, US investment in emerging nations has dwindled in recent years. While various reasons may explain this trend, perhaps the most apparent reason is the delicate balance that often exists between risk and reward (Ramcharran, 2000). This balance has proven tenuous in emerging nations. While conspicuous in form and magnitude at times, in other instances, the risk associated with an emerging nation often is intangible and based largely upon perception.

Given the previous comments and the limited amount of empirical information that exists concerning the relative and/or perceived market position of various big emerging nations as FDI alternatives, this research was conducted. The basic purpose of the research was to identify the market position of the ten big emerging nations as perceived by American business executives experienced in foreign direct investment decisions. Specific objectives of the study were to:

1. Empirically establish the perceived market position of the ten big emerging nations;

2. Develop perceived profiles of each individual nation;

3. Develop an aggregate profile of the ideal nation vis-à-vis the ten big emerging nations studied.

\section{Background}

The issue of foreign direct investment can be approached from the perspective of investing companies, as well as from that of recipient countries. There seems to be a consensus in the literature that multinational enterprises invest in foreign countries to either create a competitive advantage or sustain the competitive advantage that they were able to create in their domestic markets (Cho and Moon, 1998; Clark 1996; Ensign, 1993; Hill and Jones, 2000; Hitt 1996). This is possible because investing in foreign countries allows companies to both expand their sales and realize locational advantages. Expanding sales can help increase a company's market power and profits, and enhance its low cost position. Companies also can achieve competitive advantage by benefiting from such national resources as abundant and cheaper raw materials, readily available labor supply, lower transportation costs, and financial incentives (Earle and Estrin, 1996; Estrin and Meyer, 1998). 
However, what is unclear is the role FDI plays in the recipient countries' economic development efforts. Research has resulted in conflicting conclusions as to whether foreign direct investments are more productive than similar investments by domestic companies (Taylor, 2000). Still, it is widely recognized that FDI is playing an increasing role in the global economy. According to a United Nations report, beginning in the early 1980 s, FDI increased at an unprecedented compound annual rate of $29 \%$, reaching a world stock of FDI of $\$ 1.7$ trillion at the end of 1990 (UN, 1992). Though most of the foreign direct investment outflows go to developed economies, FDI has become a critical ingredient of the gross domestic product and gross fixed capital formation for developing economies (Dunning, 1993). As a result, FDI is increasingly becoming an important policy issue (Taylor, 2000).

As noted earlier, the 1990s witnessed a bevy of governmental initiatives that codified changes in public policies toward free enterprise and foreign direct investments in many emerging nations (Jones, 2000; Orton, 2000; Ramcharran, 2000). Several East and Central European governments (e.g., Poland and Turkey) enacted competition laws and bilateral investment treaties aimed at encouraging foreign investments (El-Said and McDonald, 2001; Hobeika, 2001; Middle East Executive Reports, 1999; Parsons, 2002; Tatoglu and Glaister, 1998). In turn, the success of these countries in their efforts to develop market-oriented economies has made them candidates for the European Union (McCrary, 2000; Orton, 2000). Clearly, nations such as these, which have initiated market-oriented economies, offer the best opportunities for multinationals seeking to invest in emerging countries. Besides these nations, India also has launched, albeit with limited success, an assault on the remnants of their old command economies (Azzam, 2001; Dhume, 2000).

The last decade of the twentieth century offered ample opportunities and challenges for foreign direct investments in emerging economies. The fall of the Berlin Wall in 1989 and the disintegration of the Soviet Union marked a turning point in the role that both multinational enterprises and national governments played in facilitating the creation of a sustainable and balanced economic environment. Now, there is virtual agreement among these, and all other nations, that foreign direct investment is beneficial (Wallace, 1990). Though much of the interest of multinational investors remains focused on developed countries, big emerging markets have been and continue to be attractive FDI alternatives (Dunning, 1988 and 1993).

Despites the progress that has been made in reforming political and economic systems, a number of challenges continue to impede the flow of foreign direct investments into emerging nations. As Dunning (1993) suggests, the most important of these challenges are the political systems, values, and ideologies that most emerging nations inherited as a result of a centralized economy. These nations still have several obstacles that need to be eradicated in order to develop market-oriented economies and attract foreign investments (Ramcharran, 2000). 
For decades, FDI was perceived as a threat to national sovereignty. As a result, government policy and legislation were devised to severely restrict foreign investments, particularly from the United States. Despite recent pro FDI changes, many emerging countries continue to suffer from this legacy (Jones, 2000). Despite its ambitious efforts, India (one of the largest BEMs) is still unable to bolster investors' confidence. The Indian Ministry of Industry has issued new guidelines on joint ventures that while easing local ownership requirements, continue to force foreign investors to waste months or even years in negotiations with Indian partners (Viswanathan, 2000).

While most big emerging nations have put in place democratic or pseudodemocratic institutions, many continue to suffer institutional instability. To implement market economies, new democracies may impose hardships on a population accustomed to the welfare state. In turn, this reliance leads to a rise in the popularity of political parties that threaten new democratic and marketoriented institutions. Thus, the prospect that these nations can at any time fall back into political and economic instability can negatively affect the perceptions that foreign investors have of these nations (Middle East Executive Reports, 2001; Townsend, 2002).

While the preceding comments explain why US firms historically have chosen to invest in Western Europe, this practice changed somewhat during the 1990s as US emphasis shifted to developing Asian and Latin American nations, most notably China and Brazil (both BEMs). Investment in each of these countries could be justified by the scope of the market opportunity alone, especially China, which has essentially retained its centralized economy. However, generally absent from this new investment mix were other, less desirable big emerging nations.

Various reasons may be posited as to why US firms have taken such a cautious approach to foreign direct investment in other big emerging nations. As noted earlier, real or perceived risk remains the most viable explanation. For example, in a global study of risk, the big emerging nation of India received overall risk composite scores of 55 (scores range from 1-100, with lower scores representing higher risk). In contrast, Switzerland received the highest overall composite risk score (94) (Erb, Harvey, and Viskanta, 1996).

Three different types of risk often are associated with a nation as a firm considers making a direct investment in that country. These risk types include the political and economic environment, domestic conditions, and economic relations (Dichtl and Koglmayr, 1986; Ramcharran, 2000). In all instances, executives charged with the responsibility for making the FDI decision must achieve "a more thorough understanding of the likelihood of various problems and opportunities in a country" (Kotabe and Helsen, 1998). This understanding, while informed, is based upon the perception(s) of that nation, region, or market. These perceptions form what is commonly known as "market position or location."

In marketing terminology, the product's "location" is its position in the mind of a consumer. In this instance, the consumer is the foreign direct investor who 
is concerned with how a product (i.e., a given nation and its "bundle of attributes") is perceived. More specifically, for foreign direct investment purposes, position refers to the investor's perception of a nation vis-à-vis a competing nation as an investment option.

\section{Positioning: Concept and Application}

The positioning concept received its first application over thirty years ago. Since that time, it has enjoyed myriad applications ranging from consumer products, to political campaigns, to job placement. According to Ries and Trout (1981), "positioning should not be confused with strategy, even though the two are inextricably related."

"Positioning starts with a product. A piece of merchandise, a service, a company, an institution, or even a person ..., but positioning is not what you do to a product. Positioning is what you do to the mind of the prospect. That is, you position the product in the mind of the prospect."

Positioning is the act of defining the product's image and value offer so that the segment's customers understand and appreciate what the product stands for in relation to its competitors (Scanlon, 1994). Stated in more pragmatic terms, for a product, business, or investment option to establish an appropriate, desirable position in the marketplace, it must demonstrate to its potential stakeholders how it differs from competing options. In so doing, the host entity (i.e., each big emerging nation) is attempting to establish a competitive advantage.

Empirically establishing the position of ten big emerging markets as FDI options was the purpose of this research. Information gleaned may offer some insight as to how and why US foreign direct investors have made their investment decisions. These findings also may contribute to future FDI investment research, as well as provide some assistance and/or direction to potential FDI recipients seeking to enhance their position as a FDI destination.

\section{Methodology}

Data for this research were obtained via a mail survey of a randomly selected sample of 500 executives chosen from the membership of the Industrial Development Research Counci] ${ }^{2}$ (IDRC 1999/2000). While membership in the IDRC includes representatives from virtually all sectors, only representatives of domestic, for-profit organizations were included in this study. A four-page, selfadministered questionnaire was developed, tested, and distributed to potential respondents with a cover letter explaining the project. The questionnaire obtained measures that identified the positions of the ten big emerging markets, as well as specific nation-related attributes. In alphabetical order, the ten big emerging markets studied included Argentina, Brazil, China, India, Indonesia, Mexico, Poland, South Africa, South Korea, and Turkey. 
The most common method for quantifying the position of an entity (i.e., a nation) vis-à-vis competing entities (i.e., nations), is through the technique of Multidimensional Scaling (MDS). This procedure converts ratings of perceived similarities to a geometric representation of several positions relative to one another. By measuring the preference concerning available options, the "ideal" option also can be portrayed on a perceptual map created from perceived similarities (Green, 1975).

One advantage of using MDS in positioning research is that, instead of evaluating each nation on a list of dimensions created by the researcher, the respondents indicate the dimensions considered when comparing foreign direct investment options. In turn, the perceptual map created is based upon multiple dimensions, representing the salient "top-of-mind" attributes the respondents associated with the BEMs studied.

To allow development of the perceptual map, respondents were asked to rate each of the ten big emerging markets with respect to similarity on a five-point Likert scale ( $1=$ Very Dissimilar to $5=$ Very Similar). Respondents then indicated which nation they preferred, as well as the primary factor upon which that rating was based. A paired-comparison format was used.

A total of 112 usable responses were received, for an overall response rate of $22.4 \%$. To detect any potential nonresponse bias, a telephone survey was conducted with 25 randomly selected nonrespondents. Nonrespondents were asked to indicate the extent of their familiarity with each of the ten nations studied. Comparisons between respondents and nonrespondents, based upon a chi-square analysis, revealed no significant $(\mathrm{p}<.1)$ differences. While some extrapolation of these findings may be possible given the minimal nonresponse bias, the questionable role that the respondents may actually play or have played in the FDI decision (this study identified only FDI experience) suggests that may limit the study's findings.

As Table 1 indicates, respondents include a variety of professionals from organizations located in all areas of the country. Manufacturing executives represented $71 \%$ of all respondents. FDI experience was divided approximately equally between executives with ten or more years of experience (51\%) and those with less than ten years of experience (49\%). Most respondents $(45 \%)$ were at the VP level, while Directors/Managers (25\%) and Presidents/CEOs accounted for the remainder $(30 \%)$. Perhaps due to a greater regional concentration, respondents from the eastern portion of the US are over represented $(51 \%)$ compared to all other regions. Thus, these findings do reflect a regional, manufacturing bias, the impact of which remains in question.

\section{Familiarity with Big Emerging Markets}

Respondents were asked to indicate their familiarity with each of the ten big emerging markets using bipolar adjectives, either extensive or limited. Extensive familiarity with a nation indicated that a respondent (his/her firm) was familiar with and had considered selecting or had selected a particular nation as 


\section{Table 1}

Description of Respondents

\begin{tabular}{lc}
\hline Region & \\
East & $51 \%$ \\
Central & $18 \%$ \\
South & $17 \%$ \\
West & $14 \%$ \\
& \\
FDI Experience & \\
Less than 10 years & $51 \%$ \\
Over 10 ycars & $49 \%$ \\
& \\
Type of Organization & \\
Manuficturing & $78 \%$ \\
Non-manufacturing & $22 \%$ \\
& \\
Position in Organization & \\
Vice President & $45 \%$ \\
Director/Manager & $25 \%$ \\
President/CEO & $30 \%$ \\
\hline
\end{tabular}

the recipient of a foreign direct investment. Limited familiarity with a nation indicated that a respondent (his/her firm) was familiar with, but had not considered that emerging nation for a foreign direct investment.

FDI decisions (as well as countless other types of decisions) should be based upon objective data. However, preliminary decisions often are influenced by perceptions of reality (Ries and Trout, 1981; Scanlon, 1994). Thus, while the development of a measure of FDI executives' "intent to invest" in each nation would have been desirable, the goal of this study was to assess nation perceptions. By assessing the respondents' familiarity with each nation, the perceptual basis for subsequent FDI responses, either favorable or unfavorable, was obtained.

As expected, all respondents were familiar with the ten big emerging markets studied. However, the degree of familiarity with each nation varied. As indicated in Table 2, respondents were most familiar with China and Mexico. Respondents were least familiar with the big emerging markets of Argentina, Indonesia, and Poland. Substantial familiarity was associated with all remaining BEMs.

\section{Perceptual Map of Big Emerging Markets}

The perceptual map of BEMs that was developed exhibited three dimensions. These are portrayed in Figure 1 as Stability of Political and Economic Systems, Availability of and Access to Markets/Resources, and Business Environment. These factors are of note because they differ from Dunning's (1988) "OLI" factors (i.e., ownership, location, and internationalization), which are widely recognized as and purported to be the basic determinants of FDI. 
Table 2

Degree of Familiarity with Big Emerging Markets

Nation

A-Argentina
B - Brazil
C - China
I- India
IN - Indonesia
M-Mexico
P- Poland
SA - South Africa
SK - South Korea
T - Turkey

T-Turkey
Extensive Familiarity (\%)

Limited Familiarity (\%)

22

17

7

12

23

3

26

12

13

13

In reviewing the findings presented as Figure 1, some clarification may be necessary. The perceived positions of all nations studied, as well as that of the ideal nation, are identified as relative points located along and above (denoted by a solid line) or below (denoted by a dotted line) the three axes (line length denotes the extent above or below the midpoint of each axis).

These findings indicate that several nations appear to be clustered together on similar dimensions. One group of nations consisting of China, India, and Mexico appear to be clustered together and are perceived as occupying the most desirable positions. All are perceived as possessing the greatest availability of and access to markets/resources. India and Mexico also are seen as offering a more accommodating environment, whereas, China suffers on this dimension. None of these three nations enjoy perceived political and economic stability.

A second group of nations, this one consisting of Brazil, Indonesia, Poland, and Turkey appear to be clustered together and are generally perceived as possessing adequate market/resource availability and access (Poland is an exception on this dimension), but are severely lacking on the dual dimensions of political and economic stability and offering an accommodating business environment.

A final group of nations consisting of Argentina, South Africa, and South Korea appear to be clustered together and are perceived to occupy an essentially neutral position overall. All three nations are seen as offering somewhat limited markets/resources, a marginally stable political and economic environment, and a somewhat accommodating business environment.

Most interestingly, India appears to occupy a unique and strategically opportunistic position. Perhaps because of the relatively recent removal of strict local ownership requirements and the fact that India has almost a billion consumers, India is viewed as a being a prime BEM/FDI destination. As can be observed in Figure 1, India's most pressing need appears to be in reaffirming the long-term 
Figure 1

\section{Perceptual Map of Big Emerging Markets}

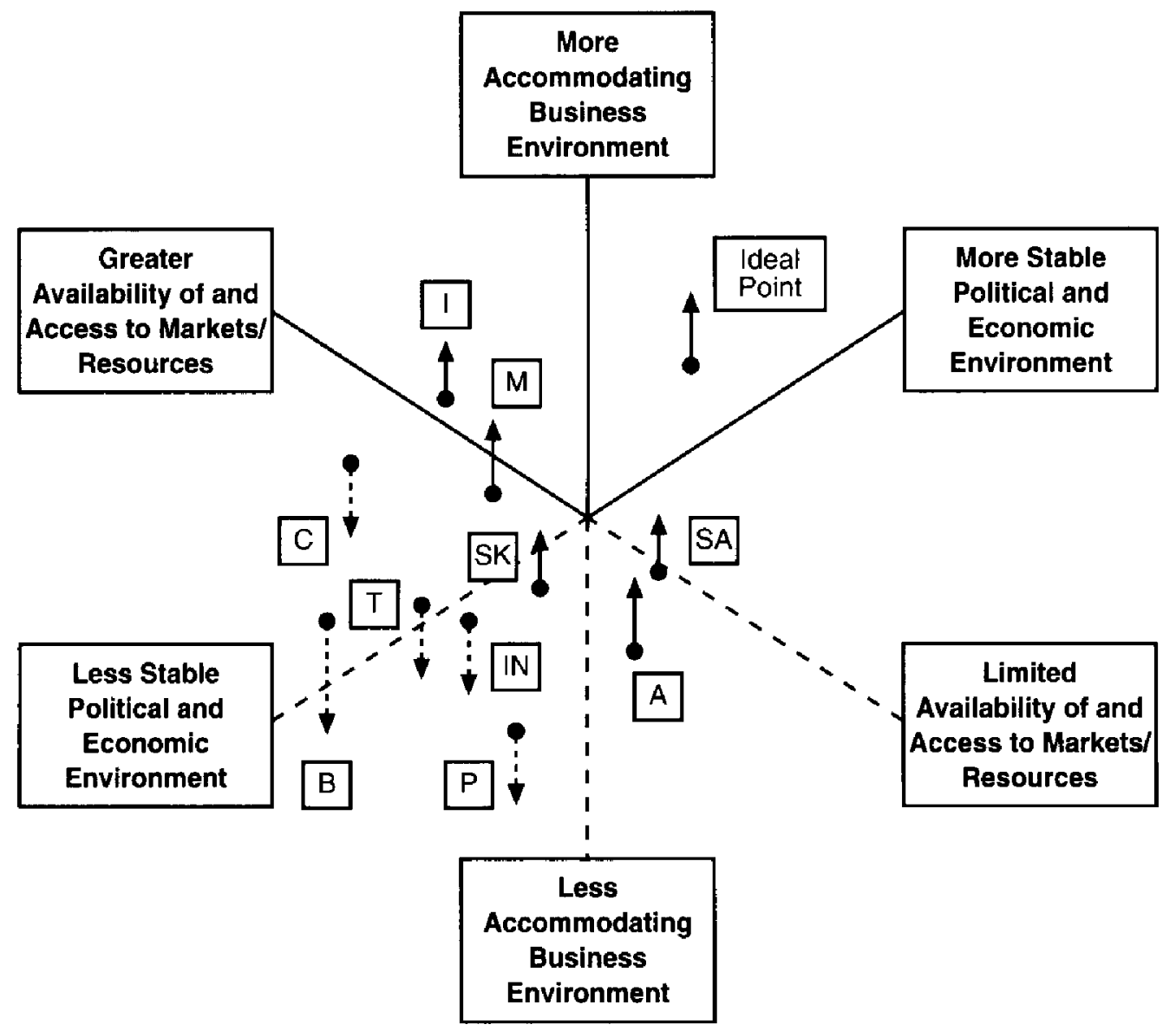

B - Brazil

IN - Indonesia

SA - South Africa
C - China

$M$ - Mexico

SK - South Korea

T - Turkey

stability of its political and economic systems. Perhaps because of its involvement in NAFTA, Mexico occupies a perceived position much like that of India. As a strategic alternative, perhaps Mexico should position itself as "the gateway to South America," thereby enhancing its availability and access to markets and resources. Additional political and economic stability also would positively contribute to its continued FDI growth.

At a nation specific level, several findings were of note. Argentina, South Africa, and South Korea, despite their dubious pasts, are regarded as enjoying a relatively accommodating business environment, modest markets and resources, and stable political and economic systems. However, none of these BEMs distinguish themselves on any of these dimensions. In turn, these findings 
suggest that these nations may enjoy the greatest array of strategic alternatives and opportunities to improve FDI.

Brazil and Poland may be considered "FDI outliers." Each occupies a somewhat unique position. Brazil is seen as having desirable markets and resources, but appears to suffer badly from political and economic instability, as well as a less accommodating business environment. Likewise, Poland occupies a position that easily may be considered the weakest of any of the BEMs studied. Given its location on all dimensions, Poland appears to hold this dubious distinction. However, two other nations appear to face significant FDI challenges. These nations include Indonesia and Turkey.

Respondents perceive the ideal nation as possessing overall qualities that can be construed as acceptable on most dimensions and conservative in the area of political and economic stability. While not specifically ascertained, it appears that FDI respondents place far greater emphasis on this latter dimension.

As noted earlier, India and China appear most strategically positioned relative to the availability of and access to markets and resources. Most other nations, except for Argentina, Poland, and South Africa, appear to occupy an acceptable or neutral position on the availability and access dimension. Half of the nations studied are perceived as possessing business climates or environments that are less than accommodating. Brazil, China, Indonesia, Poland, and Turkey are perceived as being somewhat deficient in this area. While this research did not ascertain the specific elements that comprise the business environment, this area arguably represents a strategic area of need (Kamm, 1992).

In contrast, the most difficult and traditionally dubious dimension that can be addressed is the political and economic environments of emerging nations. Three of the BEMs studied are perceived as having relatively stable environments. Those nations include India, Mexico, and South Africa. Two other nations, Argentina and South Korea occupy only slightly negative positions on this dimension. All other nations studied are perceived as having less stable environments, especially Brazil and Poland. Two nations, Indonesia and South Korea appear poised to potentially improve their positions on this dimension.

Given the overall ideal point perceived by respondents, at least two and perhaps as many as five nations appeared poised to take greatest advantage of repositioning opportunities. Most immediately, those nations include India and Mexico, with opportunities also available for Argentina, South Africa, and/or South Korea (via greater economic and political stability).

Several nations including Brazil, China, and Turkey appear to possess desirable markets and resources, but suffer mightily from unstable political and economic environments, as well as unaccommodating business environments. An effort to improve in either of these areas has the potential to generate much more FDI interest. Further, while each of these nations generally must pursue different repositioning strategies, all possess one or more qualities that make them potentially desirable foreign direct investment options. 


\section{Conclusion}

Foreign direct investments generally are recognized as providing an opportunity for nations, governments, society, and business to improve economically. As such, most nations around the globe are pursuing (to some extent) direct investments by foreign governments, companies, and private investors. The pursuit of these foreign direct investments is highly competitive. To be successful, a nation must position itself as being more desirable than another nation, especially other similar, competing nations. This study was undertaken to determine how foreign direct investment executives perceived ten BEMs.

Overall, these findings demonstrate where and how each of the ten BEMs studied is perceived individually and collectively. In turn, the foreign direct investment challenge and opportunity for each of these nations lies in its desire and ability to affect meaningful and enduring change. If this commitment can be achieved, then each nation must develop an economic development program designed to capitalize on and/or ameliorate each aspect of their perceived position.

\section{References}

Aitken, B., Hanson, G. H., \& Harrison, A. E. (1997). Spillovers, foreign investment, and export behavior. Journal of International Economics, 43, 1-2.

Azzam, H. T. (2001). Business indicators - private capital flows to the Arab countries in 2001 and 2002. Middle East Executive Reports, 24, 5 (May), 22.

Boycko, M., Shleifer, A., \& Vishny, R. W. (1994). Voucher privatization. Journal of Financial Economics, 35, 2, 34-37.

Clark, C. (1996). Privatization and industrial policy as U.S. competitiveness strategies: Lessons from East Asia. Advances in Competitiveness Research, 4, 101-118.

Cho, Dong-Sung, \& Moon, Chang (1998). A nation's international competitiveness in different stages of economic development. Advances in Competitiveness Research. $6,5-19$.

Dichtl, E., \& Koglmayr, H. G. (1986). Country risk ratings. Management International Review, 26, 4, 6 .

Dhume, S. (2000). India's awakening. Far Eastern Economic Review, (January), 36-38.

Dunning, J. H. (1988). The eclectic paradigm of international production: A restatement and some possible extensions. Journal of International Business Studies, 19, 1, 131 . 
Dunning, J. H. (1993). The Globalization of Business: The Challenge of the 1990's. Routledge, London, England.

Earle, J. S., \& Estrin, S. (1996). Employee ownership in transition. In R. Frydman, C.W. Gray, and A. Rapaczynski (Eds.), Corporate Governance in Central Europe and Russia, 2, World Bank/CEU Press, London, 1-61.

El-Said, H., \& McDonald, F. (2001). Institutions and joint ventures in the Middle East and North Africa: The case of Jordan. Journal of Transnational Management Development, $6,1 \& 2,65$.

Ensign, P. C. (1993). A system theory of foreign direct investment: Advantages of being multinational. Advances in Competitiveness Research, 1, 67-77.

Erb, C. B., Harvey, C. R., \& Viskanta, T. E. (1996). Expected returns and volatility in 135 countries. Journal of Portfolio Management, 22, (Spring), 46.

Estrin, S., \& Meyer, K. E. (1998). Opportunities and tripwires for foreign investors in Eastern Europe. Thunderbird International Business Review, 40, 3 (May/June), 209-234.

FDI in Tunisia: Restrictions easing but emphasis is still on offshore export-oriented foreign investment. Middle East Executive Reports, 24, 6 (June 2001), 4.

Garten, J. E. (1997). The Big Ten: The Big Emerging Markets and How They Will Change Our Lives, Basic Books, New York, NY.

Green, P. E. (1975). Marketing applications if MDS: Assessment and outlook. Journal of Marketing, 39, (January), 24-31.

Hill, C.W.L., \& Jones, G. R. (2000). Strategic Management Theory, Houghton-Mifflin Company, Boston, MA.

Hitt, M. A. (1996). Problems and potential solutions to strategic competitiveness in global market. Advances in Competitiveness Research, 4. 4.

Hobeika, L. G. (2001). Economic growth, privatization, trade and competition in Lebanon. Middle East Executive Reports, 24, 9 (September), 7.

International Membership and Resource Directory (1999-2000). International Development Research Council, Atlanta, GA.

Jenkins, G. (1995). Investment funds in Cuba: An upcoming Caribbean tiger. Columbia Journal of World Business, 30, 1, (Spring), 42.

Jones, C. (2000). Hungary: post-communist belle of the ball. The Banker, (July), 29-31. 
Kamm, T. (1992). Latin links. The Wall Street Journal, (September 24), R6.

Keegan, W. J., \& Green, M. C. (2003). Global Marketing, Prentice Hall Publishers, Upper Saddle River, NJ.

Kotabe, M., \& Helsen, K. (1998). Global Marketing Management, John Wiley \& Sons, Inc. New York, NY.

McCrary, E.S. (2000). Turkey rises to the EU challenge. Global Finance, (June), 49-58.

Orton, C.W. (2000). Eastern Europe meets west. World Trade, (April), 76-80.

Parsons, N. (2002). Turkey seeks partners for the long term. Global Finance, (June), 12.

Ramcharran, H. (2000). Foreign direct investments in central and eastern Europe: An analysis of regulatory and country risk factors. American Business Review, (June), $1-8$.

Ries, A., \& Trout, J. (1981). Positioning: The Battle for Your Mind. New York: McGrawHill.

Sachs, J. D., \& Warner, A. (1995). Economic reform and the process of global integration. In W. C. Brainard and G. L. Perry (Eds.), Brookings Papers on Economic Activity, 1, Washington, DC: Brookings Institute, $1-18$.

Saudi Arabia's investment climate: Debating revisions to encourage more private foreign investment. Middle East Executive Reports (1999) 22, 7, 8.

Scanlon, J. R. (1994). Site selection and design for the growth industries. Industrial Development, (March/April), 26-29.

Taylor, C. T. (2000). The impact of host country government policy on US multinational investment decisions. The World Economy, (May), 635-647.

Tatoglu, E., \& Glaister, K. W. (1998). Determinants of foreign direct investment in Turkey. Thunderbird International Business Review, 40, 3 (May/June), 279-314.

Townsend, D. (2002). Slowly does it. Petroleum Economist, 69, 4 (April), 26.

United Nations (1992). World economy survey. The Economist, (September), 17.

United Nations (1998). Economic survey of Europe, 3, Geneva: United Nations.

United Nations (1999). Economic survey of Europe, 1, Geneva: United Nations.

Viswanathan, A. (2000). Is India being fair to foreign investment? International Financial Law Review, (January), 21-23. 
Wallace, C.D. (1990). Foreign direct investment in the 1990s: A new climate in the third world. Martinus Nijhoff Publishers, Dordrecht, Netherlands.

${ }^{1}$ See multiple articles on BEMs in the Summer 1996 edition of the Columbia Journal of World Business 31, 2.

${ }^{2}$ The sample was drawn from the membership of the IDRC. However, that organization did not sponsor or endorse the project.

Troy A. Festervand is Associate Dean for Graduate and Executive Education and Professor of Marketing at Middle Tennessee State University where he teaches Industrial Marketing and International Marketing. He received his Ph.D. in 1980 from the University of Arkansas. In addition to publishing his research in numerous journals, he is actively involved in industrial consulting and professional activities. 